\title{
Transpulmonary pressure in SARS-CoV-2- associated acute respiratory distress syndrome: a single-center observational study
}

\author{
Severin Ramin ${ }^{1,2^{*}}$ D, Jonathan Charbit ${ }^{1,2}$, Geoffrey Dagod ${ }^{1,2}$, Mehdi Girard ${ }^{1,2}$, Samir Jaber $^{3,4}$ and Xavier Capdevila ${ }^{1,2}$
}

\section{Dear Editor,}

Gattinoni et al. [1] have recently described that the ARDS related to severe acute respiratory syndrome coronavirus 2 (SARS-CoV-2) was not a "typical" ARDS. Patients indeed presented a significant hypoxemia, which was surprisingly associated with a high compliance of the respiratory system. The cornerstone of current treatment is the use of "lung protective" ventilation strategy with especially maintaining sufficiently high positive end-expiratory pressures (PEEP). However, high levels of PEEP may lead to lung overdistension associated with an increase of alveolar dead space and an alteration of gas exchanges. The airway pressures commonly monitored on respirators do not reliably reflect the impact of pressures on the lung parenchyma. In contrast, transpulmonary pressures allow to highlight directly lung overdistension risk and lung properties. In order to better know this new kind of ARDS, transpulmonary pressures' assessment seems to be essential [2].

We wish to report the preliminary findings of a prospective monocentric physiological work, which is approved by the institutional ethics review board of the Montpellier University Hospital, France (IRB ID: 202000432). All consecutive ARDS adult patients with confirmed Covid-19 admitted in our critical care unit are included if they received invasive mechanical. Management of patients followed international recommendations.

\footnotetext{
* Correspondence: severin.ramin@gmail.com

${ }^{1}$ Anesthesiology and Intensive Care, Anesthesia and Critical Care Department A, Lapeyronie Teaching Hospital, Montpellier Cedex 5, France

2Département d'Anesthésie Réanimation Lapeyronie, Hôpital Lapeyronie, 371 Avenue du Doyen G. Giraud, 34090 Montpellier, France

Full list of author information is available at the end of the article
}

PEEP was set according to the low PEEP arm of the $\mathrm{PEEP} / \mathrm{F}_{\mathrm{i}} \mathrm{O}_{2}$ table used in previous trials. Esophageal pressures were recorded with Cooper Surgical ${ }^{\circ}$ device.

Sixteen patients were assessed (body mass index 29 [range $26-31] \mathrm{kg} / \mathrm{m}^{2}$, age 70 years [range $61-72$ years]). The median worst value of $\mathrm{PaO}_{2} / \mathrm{F}_{\mathrm{i}} \mathrm{O}_{2}$ ratio was 144 $\mathrm{mmHg}$ [range 138-149 mmHg]. Baseline of patient characteristics may be observed in the Table 1. Six patients received at least one session of prone positioning. One of them also benefited from VV-ECMO. We observed that median transpulmonary end-expiratory pressure was positive during mechanical ventilation $\left(2 \mathrm{~cm} \mathrm{H}_{2} \mathrm{O}\right.$ at D1 [range $-1-3 \mathrm{~cm} \mathrm{H}_{2} \mathrm{O}$ ]) and median transpulmonary elastance $\left(\mathrm{E}_{\mathrm{L}}\right)$ remained low at day $1\left(19 \mathrm{~cm} \mathrm{H}_{2} \mathrm{O} / \mathrm{L}\right.$ [range $8-20 \mathrm{~cm} \mathrm{H}_{2} \mathrm{O} / \mathrm{L}$ ]) and during the first week. All our findings are shown in Fig. 1.

Many reports have highlighted specificities of SARS$\mathrm{CoV}-2$, particularly that the elastance of respiratory system $\left(E_{R S}\right)$ was slightly altered. Driving pressures of the respiratory system are therefore quite low in these patients. Unsurprisingly, our study showed that the $E_{\mathbf{L}}$ was not elevated in the first days of mechanical ventilation. The main finding of the present work is that endexpiratory transpulmonary pressure remained positive in most patients with the use of moderate PEEP (8-13 $\mathrm{cm} \mathrm{H}_{2} \mathrm{O}$ ). To summarize, our analysis is in agreement with the descriptions of Gattinoni et al. [3]. Most of these patients present indeed low $\mathrm{E}_{\mathrm{RS}}$, low ventilation to perfusion ratio $(\mathrm{VA} / \mathrm{Q})$, and low lung recruitability due to the low amount of non-aerated tissue (L profile). Hypoxemia and intrapulmonary shunt might thus be better explained by dysregulation of pulmonary perfusion and by alteration of hypoxic vasoconstriction. This would 
Table 1 Baseline characteristics of the patients and respiratory mechanics $(n=16)$

\section{Characteristics}

\begin{tabular}{|c|c|}
\hline Male, $n(\%)$ & $11(69)$ \\
\hline Age (years) & $70(61-72)$ \\
\hline Body mass index $\left(\mathrm{kg} / \mathrm{m}^{2}\right)$ & $29(26-31)$ \\
\hline \multicolumn{2}{|l|}{ Organ failure at baseline (SOFA), $n(\%)$} \\
\hline Hemodynamic & $12(75)$ \\
\hline Renal & $4(25)$ \\
\hline Hepatic & $2(13)$ \\
\hline Hematological & $1(6)$ \\
\hline \multicolumn{2}{|l|}{ Arterial blood gas } \\
\hline $\mathrm{PaO} 2 / \mathrm{FiO} 2$ ratio & $170(150-208)$ \\
\hline $\mathrm{pH}$ & $7.43(7.38-7.47$ \\
\hline $\mathrm{PaO} 2(\mathrm{mmHg})$ & $71(62-89)$ \\
\hline $\mathrm{PaCO} 2(\mathrm{mmHg})$ & $40(37-45)$ \\
\hline Lactates (mmol/l) & $1.2(1-1.4)$ \\
\hline \multicolumn{2}{|l|}{ Radiologic characteristics, $n$ (\%) } \\
\hline Bilateral pneumonia & $4(25)$ \\
\hline Multiple mottling and ground-glass opacity & $12(75)$ \\
\hline Time between admission and intubation (day) & $2(2-3)$ \\
\hline \multicolumn{2}{|l|}{ Respiratory mechanics at day 1} \\
\hline Tidal volume (ml/kg PBW) & $7(6.6-7.3)$ \\
\hline Respiratory rate (beats/min) & $22(20-24)$ \\
\hline PEEPtot,rs $\left(\mathrm{cm} \mathrm{H}_{2} \mathrm{O}\right)$ & $10(10-13)$ \\
\hline PEEPtot,es $\left(\mathrm{cm} \mathrm{H}_{2} \mathrm{O}\right)$ & $8(8-12)$ \\
\hline PEEPtot,L $\left(\mathrm{cm} \mathrm{H}_{2} \mathrm{O}\right)$ & $2(-1-3)$ \\
\hline Pplat,rs $\left(\mathrm{cm} \mathrm{H}_{2} \mathrm{O}\right)$ & $19(18-22)$ \\
\hline Pplat,es $\left(\mathrm{cm} \mathrm{H}_{2} \mathrm{O}\right)$ & $13(11-16)$ \\
\hline Pplat, $\mathrm{L}\left(\mathrm{cm} \mathrm{H}_{2} \mathrm{O}\right)$ & $6(6-11)$ \\
\hline DP,rs $\left(\mathrm{cm} \mathrm{H}_{2} \mathrm{O}\right)$ & $9(6-12)$ \\
\hline $\mathrm{DP}, \mathrm{cW}\left(\mathrm{cm} \mathrm{H}_{2} \mathrm{O}\right)$ & $5(3-5)$ \\
\hline $\mathrm{DP}, \mathrm{L}\left(\mathrm{cm} \mathrm{H} \mathrm{H}_{2} \mathrm{O}\right)$ & $4(2-9)$ \\
\hline Est,rs (cm H$\left.{ }_{2} \mathrm{O} / \mathrm{L}\right)$ & $23(18-30)$ \\
\hline Est,cw $\left(\mathrm{cm} \mathrm{H}_{2} \mathrm{O} / \mathrm{L}\right)$ & $4(4-10)$ \\
\hline $\mathrm{Est}, \mathrm{L}\left(\mathrm{cm} \mathrm{H} \mathrm{H}_{2} \mathrm{O} / \mathrm{L}\right)$ & $19(8-20)$ \\
\hline
\end{tabular}

Results are expressed as median (IQR) or as number of patients (percentage) as appropriate

PBW, predicted body weight; SOFA, sepsis-related organ failure; PEEPtot,rs,

static end-expiratory pressure of the respiratory system; PEEPtot,es, static endexpiratory esophageal pressure; PEEPtot, L, static end-expiratory transpulmonary pressure; Pplat,rs, static end-inspiratory pressure of the respiratory system; Pplat,es, static end-inspiratory esophageal pressure; Pplat, $L$, static end-inspiratory transpulmonary pressure; $D P, r s, D P, C W, D P, L$, driving pressure of respiratory system, chest wall, and lung, respectively; Est,rs, Est,cw, $E s t, L$, static elastance of respiratory system, chest wall, and lung, respectively 

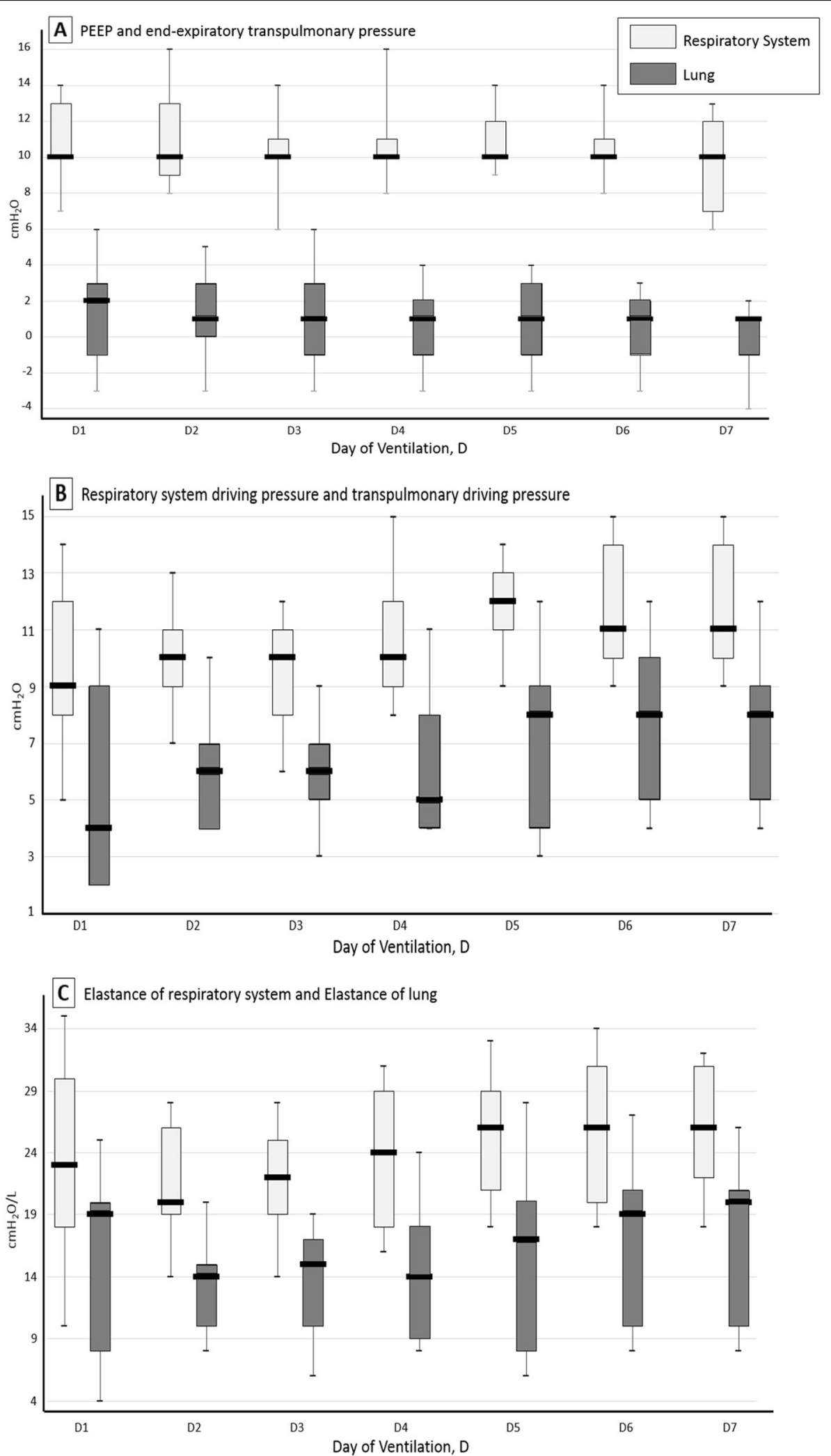

Fig. 1 (See legend on next page.) 
(See figure on previous page.)

Fig. 1 Respiratory physiological measures during mechanical ventilation. Boxes represent median and interquartile range. The number of patients with available respiratory physiological data decreases over successive study days due to deaths and discontinuation of invasive mechanical ventilation. Transpulmonary pressure (PL) equals respiratory system pressure minus esophageal pressure. Respiratory system driving pressure equals plateau pressure minus positive end expiratory pressure (PEEP). Transpulmonary driving pressure equals end-inspiratory PL minus end-expiratory PL

justify the use of moderate levels of PEEP to limit alveolar dead space and optimize the $\mathrm{CO}_{2}$ removal. Gattinoni et al. [4] also described that $20-30 \%$ of patients presented a delayed aggravation with more usual pulmonary parameters: high $\mathrm{E}_{\mathrm{RS}}$, high right-to-left shunt, high lung recruitability ( $H$ profile). Constitution of atelectasis or bacterial overinfection is associated with $H$ profile. This is observable in our series since a part of patients experienced an increase of $E_{R S}$ as $E_{L}$ (Fig. 1c). For the latter, elevated PEEP seems to be more legitimate [5]. To conclude, identification of respiratory phenotype seems therefore essential in ventilated SARS-CoV-2 patients to determine optimal mechanical ventilation strategy. Our observations support the concept of using low PEEP in a large part of SARS-CoV-2 patients.

\section{Acknowledgements}

No acknowledgements.

\section{Authors' contributions}

SR, JC, and XC conceived of the study. SR, JC, and SJ analyzed the data. SR, JC, SJ, and XC drafted the manuscript. All authors interpreted the data, revised the manuscript, and approved the final version.

\section{Funding}

No finding received.

Availability of data and materials

Not applicable.

\section{Ethics approval and consent to participate}

Institutional ethics review board of the Montpellier University Hospital, France (IRB ID: 202000432).

\section{Consent for publication}

Obtained.

\section{Competing interests}

No competing interests.

\section{Author details}

'Anesthesiology and Intensive Care, Anesthesia and Critical Care Department A, Lapeyronie Teaching Hospital, Montpellier Cedex 5, France. ${ }^{2}$ Département d'Anesthésie Réanimation Lapeyronie, Hôpital Lapeyronie, 371 Avenue du Doyen G. Giraud, 34090 Montpellier, France. ${ }^{3}$ Anesthesiology and Intensive Care, Anesthesia and Critical Care Department B, Saint Eloi Teaching Hospital, PhyMedExp, University of Montpellier, INSERM U1046, CNRS, UMR 9214, 80 Avenue Augustin Fliche, 34295 Montpellier Cedex 5, France. ${ }^{4}$ Département d'Anesthésie Réanimation Saint-Eloi, Hôpital Saint-Eloi, 80 Avenue Augustin Fliche, 34090 Montpellier, France.
Received: 27 May 2020 Accepted: 1 July 2020

Published online: 09 July 2020

\section{References}

1. Gattinoni L, Coppola S, Cressoni M, Busana M, Chiumello D. Covid-19 does not lead to a "typical" acute respiratory distress syndrome. Am J Respir Crit Care Med. 2020;201(10):1299-300.

2. Gattinoni L, Giosa L, Bonifazi M, Pasticci I, Busana M, Macri M, et al. Targeting transpulmonary pressure to prevent ventilator-induced lung injury. Expert Rev Respir Med. 2019;13(8):737-46.

3. Gattinoni L, Chiumello D, Caironi P, Busana M, Romitti F, Brazzi L, et al. COVID-19 pneumonia: different respiratory treatments for different phenotypes? Intensive Care Med. 2020;46(6):1099-102.

4. Gattinoni L, Chiumello D, Rossi S. COVID-19 pneumonia: ARDS or not? Crit Care Lond Engl. 2020;24(1):154.

5. Marini JJ, Gattinoni L. Management of COVID-19 respiratory distress. JAMA. 2020;323(22):2329-30.

\section{Publisher's Note}

Springer Nature remains neutral with regard to jurisdictional claims in published maps and institutional affiliations.

\footnotetext{
Ready to submit your research? Choose BMC and benefit from:

- fast, convenient online submission

- thorough peer review by experienced researchers in your field

- rapid publication on acceptance

- support for research data, including large and complex data types

- gold Open Access which fosters wider collaboration and increased citations

- maximum visibility for your research: over $100 \mathrm{M}$ website views per year

At BMC, research is always in progress.

Learn more biomedcentral.com/submissions
} 